УДК 581.1:[582.930.3:661.162.66]

https://doi.org/10.33989/2021.7.1.243444

O.S. Talalayeva, V.V. Rohach, V.G. Kur'jata, T.I. Rohach

Vinnytsia Mychailo Kotsubynsky State Pedagogical University

Ostrozhskogo Street, 32, Vinnytsia, 21100, Ukraine

E-mail:rogachv@ukr.net

ORCID 0000-0002-2943-1598

ORCID 0000-0002-8916-8349

ORCID 0000-0002-6763-8266

ORCID 0000-0002-7801-933X

\title{
FEATURES OF THE MESOSTRUCTURAL ORGANIZATION OF THE LEAVE AND THE ANATOMICAL STRUCTURE OF THE TOBACCO STEM UNDER THE ACTION OF GROWTH STIMULATORS
}

Anotation. Tobacco plants of Ternopil 14 variety were treated with growth stimulants 1-NAA, GA3 and 6-BAP in the budding phase. Under the influence of growth stimulants, tobacco leaf blades thickened due to the growth of chlorenchyma. The greatest increase in leaf thickness was found after the application of GA3. 1-NAA and GA3 increased the volume of columnar parenchyma cells. The size of the cells of the spongy parenchyma under the action of growth regulators did not change significantly. It was found that 1-NAA reduced the number of epidermal cells and the number of stomata per unit abaxial surface of the leaf, and under the action of 6-BAP, these indicators increased authentically. GA3 increased the number of epidermal cells and decreased the number of stomata. All growth stimulants reduced the area of the stomata. Growth stimulants thickened the collenchyma layer and increased or did not change the size of sclerenchymal fiber cells. The thickness of the shells of sclerenchyma cells increased significantly only with the use of 6-BAP. Under the action of other growth stimulants, this indicator had only a tendency to increase. 1-NAA and 6-BAP increased the thickness of the secondary layer and decreased the primary periderm. Under the action of GA3, the layers of the primary and secondary periderm became thinner. The drugs increased the thickness of the xylem and the diameter of the largest vessels.

Key words: Nicotiana tabacum; plant growth stimulants; leaf mesostructured; stem anatomy.

Introduction. The leaf is the main assimilation organ of the plant, the efficiency of which depends on the growth, development and biological productivity of crops. Growth stimulants are a group of natural and synthetic compounds of various origins that activate growth processes in plants, including through the optimization of the structure of the photosynthetic apparatus. In the literature there are isolated data on the influence of growth-stimulating compounds on the mesostructural organization of leaves and the structure of the respiratory system. In particular, the use of gibberellic (GA3) and 1-naphthylacetic acids (1-NAA) on Eriobotrya japonica plants reduced the number of stomata and increased their area, while the action of 6-benzylaminopurine (6-BAP) increased the number of stomata and decreased their area (Surya et al, 2020).

Treatment of plants Epipremnum aureum 1-NAA and 6-BAP in doses of 5, 50 and $100 \mathrm{mg} / \mathrm{l}$ separately or in sequential treatment thickened the leaf blades, increased the size of epidermal cells and stomata. Under the action of the drug, the epidermis became thinner and the assimilation parenchyma thickened. The volume of intercellular space in the spongy parenchyma did not change. The most effective dose was $50 \mathrm{mg}$ (Benedetto, Galmarini, \& Tognetti Benedetto et al, 2016).

In other studies, 6-BAP promoted the growth of isolated Capsicum annuum leaves and their assimilation parenchyma (Nielsen, \& Ulvskov, 1992).

Thickening of the chlorenchyma under the action of the cytokinin growth stimulator treptolem was also recorded in plants Heliannthus annuus of the Flagsman variety, Linum usitatissimum of the Orpheus variety (Khodanitska et al, 2019) and Papaver somniferum of the Berke variety.

Growth stimulants also affected the anatomical structure of the stem of crops prone to lodging. Thus, treptol thickened the stems of Linum usitatisissimum by increasing the thickness of the bark, 
xylem and diameter of the bast fibers (Khodanitska et al, 2019). The same drug thickened the collenchyma and sclerenchymal cell fiber shells in Heliannthus annuus plants, increased the size of sclerenchyma cells and the number of rows of collenchyma cells (Rogach, \& Kuryata, 2018).

Material and method. The research was carried out on the nasadzhennyas of the tyutyun in the SFG "Berzhan P.G." from. Gorbanivka in the Vinnytsia district of the Vinnytsia region. Plants of Ternopilskiy 14 variety were handled with the help of the knapsack sprayer CO-12 "Marolex" with growth stimulants with 1-naphthylacetic acid, hyberelic acid and 6-benzylaminopurine. Control plants were perfused with tap water. The collection of materials for the formation of mesostructural organization of the leaf and anatomical buds and stems were carried out at the phase of flowering. For its preservation, were added the mixture in equal proportions of ethyl alcohol, glucerin, and $1 \%$ formalin (Kuryata, 1999).

Measurement of the size of the cells, fabric, organs, diameter of the vessels was taken using the microscope "Mikmed-1" and the ocular micrometer MOV-1-15 $\times$. For this was taken a piece of maceration of the fabric of the leaf. The macerating agent was $5 \%$ concentration of octic acid in $2 \mathrm{~mol} / \mathrm{l}$ chloride acid (Kuryata, 1999). For mesostructural analysis, leaflets of the same tier were taken. Repetition of mesostructural researches thirty five times.

The results were analyzed statistically using the additional computer programs Statistica 6.0. A one-factor dispersion analysis was used (the differences between the average values were counted according to the Student's criterion, and they were rated as the authentically ones for $\mathrm{P}<0.05$ ).

Results and discussion. The mesostructural organization of a leaf in many respects defines efficiency of the photosynthetic device of a plant and by that essentially influences its productivity. According to the literature, the treatment of plants with growth regulators in most cases causes changes in the anatomical structure of the leaves. In particular, the thickening of leaves at the expense of to the assimilation parenchyma was previously observed in potato plants (Rohach et al, 2020b), tomatoes (Rohach et al, 2020a), peppers (Brovko, 2016) and eggplant (Rogach, 2017).

The results of our research show that synthetic analogues of the main stimulant hormones significantly influenced the mesostructural organization of tobacco leaves of Ternopil 14 variety (Table 1). In particular, growth activators thickened or did not alter the cells of the upper and lower epidermis. The drugs thickened the leaf blades due to the cells of the main assimilation parenchyma. The most significant increase in the thickness of the chlorenchyma was recorded under the action of GA3 (14\%). Synthetic analogues of auxin and cytokinin increased the thickness of photosynthetic tissue by 6 and 5\%. At the same time, the volume of cells of the columnar parenchyma authentically increased under the action of 1-NAA and GA3 (17 and 31\%). After the use of 6-BAP, this figure did not change authentically. Growth stimulators did not practically change the size of the cells of the spongy parenchyma.

Growth stimulants are known to affect the respiratory system of plants.

We established that the synthetic analogue of auxin reduced the number of epidermal cells and the number of stomata per unit abaxial surface of the leaf, while under the action of synthetic cytokinin, these figures increased authenticaly. GA3 increased the number of epidermal cells and decreased the number of stomata. All growth stimulants reduced the area of the respiratory cells.

Thus, the thickening of the leaf blades due to the growth of the chlorenchyma cell layer and the increase in the volume of the columnar parenchyma cells can create the preconditions for increasing the photosynthetic activity of plants and increase the biological productivity of tobacco culture. Reducing the size and number of stomata may be a precondition for reducing the evaporation of water from the plant, and this is increase its resistance to lack of moisture in arid growing conditions. Moreover, the reduction of the airway surface is a limiting factor in the supply of carbon dioxide to the leaf, which can help slow down the photosynthetic processes in the plant.

Lying down of tobacco crops is one of the determining factors influencing the quantitative and qualitative indicators of crop yield. Therefore, it is important to establish the effect of growth stimulants on stem thickness and their strength and resistance to lodging. The results of our studies show that growth stimulants thickened the layer of mechanical tissue - collenchyma by $14-21 \%$ 
Table 1

Influence of growth stimulants on the mesostructure of tobacco leaves of Ternopil 14 variety

\begin{tabular}{|c|c|c|c|c|}
\hline Indicators & Control & 1-NAA & $\mathrm{GA}_{3}$ & 6-BAP \\
\hline The thickness of the upper epidermis, $\mu \mathrm{m}$ & $22,65 \pm 0,45$ & ${ }^{\star} 19,77 \pm 0,21$ & $* 21,05 \pm 0,27$ & $21,78 \pm 0,42$ \\
\hline The thickness of the chlorenchyma, $\mu \mathrm{m}$ & $172,44 \pm 3,02$ & ${ }^{\star} 183,24 \pm 4,37$ & ${ }^{\star} 195,85 \pm 5,26$ & ${ }^{*} 181,78 \pm 2,99$ \\
\hline The thickness of the lower & $16,03 \pm 0,54$ & $16,64 \pm 0,39$ & ${ }^{\star} 13,86 \pm 0,45$ & ${ }^{\star} 13,03 \pm 0,45$ \\
\hline Leaf blade thicknes & $211,12 \pm 3,01$ & 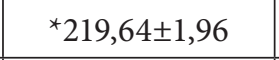 & $\star 230,77 \pm 1,99$ & $216,51 \pm 6,87$ \\
\hline Columnar parenchyma cell volume $\mu \mathrm{m}^{3}$ & $10322,78 \pm 511,61$ & $\star 12035,42 \pm 575,27$ & ${ }^{\star} 13505,76 \pm 90,09$ & 9095,52 \\
\hline $\begin{array}{l}\text { The length of the cells of the spongy pare } \\
\text { chyma, } \mu \mathrm{m}\end{array}$ & $24,93 \pm 0,49$ & $22,21 \pm 0,41$ & $26,92 \pm 0,63$ & $24,16 \pm 0,51$ \\
\hline $\begin{array}{l}\text { The width of the cells of the spongy } \\
\text { parenchyma, } \mu \mathrm{m}\end{array}$ & $21,98 \pm 0,44$ & $18,84 \pm 0,43$ & $19,43 \pm 0,41$ & $18,38 \pm 0,56$ \\
\hline $\begin{array}{l}\text { The number of epidermal cells, pcs. / } \mathrm{mm} 2 \\
\text { abaxial surface of the leaf }\end{array}$ & $2162,45 \pm 22,53$ & ${ }^{\star} 1966,43 \pm 28,32$ & $\star 2224,97 \pm 18,41$ & $\star 2372,37 \pm 19,83$ \\
\hline $\begin{array}{l}\text { Number of stomata, pcs. / } \mathrm{mm} 2 \text { abaxial } \\
\text { surface of the leaf }\end{array}$ & $1071,97 \pm 15,21$ & $\star 880,57 \pm 12,59$ & $* 883,66 \pm 10,94$ & ${ }^{\star} 1135,25 \pm 17,24$ \\
\hline The area of the cells of the stomata, $\mu \mathrm{m}^{2}$ & $65,95 \pm 0,94$ & $* 62,23 \pm 1,22$ & $\star 62,4 \pm 0,89$ & $64,36 \pm 1,29$ \\
\hline
\end{tabular}

Note. ${ }^{*}$ - the difference is authentically by $\mathrm{P} \leq 0.05$.

and increased or did not change the size of sclerenchymal fiber cells. The thickness of the shells of sclerenchyma cells increased authentically only with the use of a synthetic analogue of cytokinins. Under the action of other growth stimulants, this indicator had only a tendency to increase. 1-NAA and 6-BAP increased the thickness of the secondary layer and decreased the primary periderm. Under the action of GA3 there was a thinning of the layers of the primary and secondary periderm.

Growth stimulants increased the thickness of the xylem layer by $19-43 \%$ and the diameter of the largest vessels by 11-18\%. Increasing the thickness of the layer of cells of the primary and secondary periderm and xylem, increasing the size of cells of sclerenchymal fibers and thickening of their cell shells will increase the mechanical strength of the stem and the resistance of plants to lodging.

Table 2

\section{Influence of growth stimulants on the anatomical structure of the tobacco of Ternopil 14 variety}

\begin{tabular}{|c|c|c|c|c|}
\hline A variant of the experiment & Control & 1-NAA & GA3 & 6-BAP \\
\hline The thickness of the epidermis, $\mu \mathrm{m}$ & $4,55 \pm 0,08$ & $4,53 \pm 0,09$ & $\star 5,31 \pm 0,09$ & $\star 5,21 \pm 0,08$ \\
\hline $\begin{array}{l}\text { The thickness of the layer of the primary } \\
\text { periderm, } \mu \mathrm{m}\end{array}$ & $42,19 \pm 0,45$ & $\star 35,26 \pm 1,08$ & $\star 29,77 \pm 0,68$ & $\star 33,03 \pm 0,39$ \\
\hline $\begin{array}{l}\text { The thickness of the layer of the collenchy- } \\
\text { ma, } \mu \mathrm{m}\end{array}$ & $71,32 \pm 1,02$ & ${ }^{*} 82,56 \pm 1,64$ & $\star 86,04 \pm 2,17$ & ${ }^{\star} 86,14 \pm 1,24$ \\
\hline The length of sclerenchyma cells, $\mu \mathrm{m}$ & $31,63 \pm 0,71$ & $\star 42,08 \pm 1,28$ & $31,32 \pm 0,81$ & $* 33,98 \pm 0,65$ \\
\hline The width of sclerenchyma cells, $\mu \mathrm{m}$ & $19,54 \pm 0,64$ & $\star 27,64 \pm 0,81$ & $21,17 \pm 0,83$ & $19,12 \pm 0,32$ \\
\hline $\begin{array}{l}\text { The thickness of the shell of sclerenchyma } \\
\text { cells, } \mu \mathrm{m}\end{array}$ & $1,70 \pm 0,08$ & $1,82 \pm 0,07$ & $1,74 \pm 0,7$ & ${ }^{\star} 1,89 \pm 0,05$ \\
\hline $\begin{array}{l}\text { The thickness of the layer of the secondary } \\
\text { periderm, } \mu \mathrm{m}\end{array}$ & $420,64 \pm 4,85$ & $\star 526,39 \pm 7,54$ & $\star 315,24 \pm 4,66$ & ${ }^{\star} 438,78 \pm 4,54$ \\
\hline The thickness of the xylem layer, $\mu \mathrm{m}$ & $372,41 \pm 4,15$ & $\star 532,08 \pm 6,28$ & ${ }^{*} 444,21 \pm 11,34$ & $\star 508,12 \pm 7,91$ \\
\hline $\begin{array}{l}\text { The diameter of the largest vascular xylems, } \\
\mu \mathrm{m}\end{array}$ & $53,43 \pm 0,68$ & 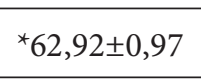 & $\star 59,28 \pm 0,82$ & ${ }^{*} 62,67 \pm 1,06$ \\
\hline
\end{tabular}

Note. ${ }^{*}$ - the difference is authentically by $\mathrm{P} \leq 0.05$.

Conclusions. During the treatment of tobacco plants with growth stimulants, the leaf blades were thickened due to the growth of chlorenchyma, namely the cells of the columnar parenchyma, which may be a prerequisite for increasing photosynthetic activity. Under the action of drugs, the thickness of the collenchyma and xylem increased, which enlarged the diameter of the stem and increased the resistance of plants to lodging. 


\section{References}

Brovko, O. V., Kur'jata, V. H., \& Rohach, V. V. (2016). Vplyv syntetychnykh reghuljatoriv rostu 1-NOK ta 6-BAP na morfoghenez ta produktyvnistj percju solodkogho [The influence of synthetic growth regulators 1-NAA and 6-BAP on the morphogenesis and the productivity of sweet pepper]. Visnyk Ljvivsjkogho nacionaljnogho aghrarnogho universytetu. Serija Aghronomija, 1, 1-8 [in Ukrainian].

Di Benedetto, A., Galmarini, C., \& Tognetti, J. (2015). Effects of combined or single exogenous auxin and/or cytokinin applications on growth and leaf area development in Epipremnum aureum. The Journal of Horticultural Science and Biotechnology, 90(6), 643-654. doi: 10.1080/14620316.2015.11668727

Khodanitska, O. O., Kuryata, V. G., Shevchuk, O. A., Tkachuk, O. O., \& Poprotska, I. V. (2019). Effect of treptolem on morphogenesis and productivity of linseed plants. Ukrainian Journal of Ecology, 9(2), 119-126.

Kur'jata, V. H. (1999). Fiziologho-biokhimichni mekhanizmy diji retardantiv i etylenproducentiv na roslyny jaghidnykh kuljtur [Physiological and biochemical mechanisms of action of retardants and ethylene producers on berry crops]. (D.dis). Kyiv [in Ukrainian]

Kur’jata, V. H., \& Polyvanyi, S. V. (2018). Osoblyvosti funkcionuvannja donorno-akceptornoji systemy maku olijnogho za diji treptolemu $\mathrm{v}$ zv'jazku z produktyvnistju kuljtury [Formation and functioning of source-sink relation system of oil poppy plants under treptolem treatment towards crop productivity]. Ukrainian Journal of Ecology, 8(1), 11-20 [in Ukrainian]. doi: 10.15421/2017_182

Nielsen, T. H., \& Ulvskov, P. (1992). Cytokinins and leaf development in sweet pepper (Capsicum annuum L.). Planta, 188, 78-84. doi:https://doi.org/10.1007/BF00198942

Polyvanyj, S. V., \& Golunova, L. A. (2020). Anatomichni osoblyvosti budovy lystkovogho aparatu roslyn ghirchyci biloji za diji stymuljatoriv rostu [Anatomic characteristics of the structure of the leaf apparatus of white mustard plants under the action of growth stimulants]. Biologhija ta ekologhija, 6(1-2), 48-50 [in Ukrainian].

Rohach, T. I. (2018). Fiziologhichni osnovy reghuljaciji morfoghenezu ta produktyvnosti sonjashnyku za dopomoghoju khlormekvatkhlorydu i treptolemu [Physiological bases of adjusting of morphogenesis and productivity of sunflower by chlormequat-chloride and treptolem]. Vinnytsia [in Ukrainian].

Rohach, V. V. (2017). Vplyv stymuljatoriv rostu na fotosyntetychnyj aparat, morfoghenez i produkcijnyj proces baklazhana (Solanum melongena) [Influence of growth stimulants on photosynthetic apparatus, morphogenesis and production process of eggplant (Solanum melongena)]. Biosystems Diversity, 25(4), 297-303 [in Ukrainian]. doi:10.15421/011745

Rohach, V. V., Kiriziy, D. A., Stasik, O. O., Mickevicius, S., \& Rohach, T. I. (2020). The effect of growth promotors and retardants on the morphogenesis, photosynthesis and productivity of tomatoes (Lycopersicon esculentum Mill.). Fiziologhija roslyn $i$ ghenetyka, 52(4), 279-294. doi: https://doi.org/10.15407/frg2020.04.279

Rohach, V. V., Rohach, T. I., Kylivnyk, A. M., Polyvanyi, S. V., Bayurko, N. V., Nikitchenko, L. O., Tkachuk, O. O., Shevchuk, O. A., Hudzevych, L. S., \& Levchuk, N. V. (2020). The influence of synthetic growth promoters on morphophysiological characteristics and biological productivity of potato culture. Modern Phytomorphology, 14, 111-114.

Surya, M. I., Ismaini, L., Normasiwi, S., Putri, D. M. \& Kurniawan, V. (2020). Plant Growth Regulators Affecting Leaf Traits of Loquat Seedling. Annual Research \& Review in Biology, 35(11), 73-85. doi:https://doi.org/10.9734/arrb/2020/v35i1130301

\section{О.С. Талалаєва, В.В. Рогач, В.Г. Кур'ята, T.I. Рогач}

Вінницький Державний Педагогічний Університет Імені Михайла Коцюбинського

\section{ОСОБЛИВОСТІ МЕЗОСТРУКТУРНОЇ ОРГАНІЗАЦІЇ ЛИСТКА ТА АНАТОМІЧНОЇ БУДОВИ СТЕБЛА ТЮТЮНУ ЗА ДІЇ СТИМУЛЯТОРІВ РОСТУ}

Анотація. Рослини тютюну сорту Тернопільський 14 обробляли стимуляторами росту 1-НОК, ГК з та 6-БАП у фазу бутонізації. Під впливом стимуляторів росту потовщувалися листкові пластинки тютюну за рахунок розростання хлоренхіми. Найбільще зростання товщини листків встановлено після застосування ГК . 1-НОК та ГК збільшували об'єм клітин стовпчастої паренхіми. Розміри клітин губчастої паренхіми за дії регуляторів росту достовірно не змінювалися. Встановлено, що 1-НОК зменшувала кількість клітин епідермісу та кількість продихів на одиницю абаксіальної поверхні листка, а за дії 6-БАП ці показники достовірно зростали. ГК збільшувала кількість клітин епідермісу та зменшувала кількість продихів. Усі стимулятори росту зменшували площу продихів. Стимулятори росту потовщували шар коленхіми та збільшували або не змінювали розміри клітин склеренхімних волокон. Товщина оболонок клітин склеренхіми достовірно зростала лище при застосуванні 6-БАП. За діі інших стимуляторів росту даний показник мав тише тенденцію до зростання. 1-НОК та 6-БАП збільшували товщину шару вторинної та зменшували первинної перидерми. За дії ГК зиари первинної та вторинної перидерми ставали тоншими. Препарати збільшували товщину ксилеми та діаметр найбільщих судин.

Ключові слова: Nicotiana tabacum; стимулятори росту рослин; мезоструктура листків; анатомія стебла. 